\title{
Respiratory Health Effects of Air Pollution and Climate Parameters in the Population of Drobeta Turnu-Severin, Romania
}

\author{
Cristina Petrescu ${ }^{1}$, Oana Suciu ${ }^{1}$, Romanita Ionovici ${ }^{2}$, \\ Olf Herbarth ${ }^{3}$, Ulrich Franck ${ }^{4}$ and Uwe Schlink ${ }^{4}$ \\ 1"Victor Babes" University of Medicine and Pharmacy Timisoara, \\ ${ }^{2}$ Public Health Authority Mehedinti, \\ ${ }^{3}$ Faculty of Medicine, University Leipzig, \\ ${ }^{4}$ Helmholtz Centre for Environmental Research - UFZ Leipzig, \\ 1,2Romania \\ 3,4 Germany
}

\section{Introduction}

Air pollution represents a problem for the population's health in Drobeta Turnu-Severin, south-west Romania since 1970, when heavy industry started developing fast. Political openings to the western world created opportunities for great investments and development of industry. The impact of air pollution on health became a major concern, especially when a Heavy Water Plant was built on the northern side of the city. Some acute accidents occurred in this Plant and, in order to prevent them, an efficient and modern monitoring system and special protection perimeters were created. Severe accidents disappeared and the values of $\mathrm{H}_{2} \mathrm{~S}$ (hydrogen sulphide) were kept at very low levels. The population's reaction to the air pollution risk decreased in time. Instead, there were air pollution sources that emitted for a long period of time particulate matter (PM) at very high levels, and gases. A Paper Plant and numerous Power Plants necessary to sustain the heavy industry became significant sources of air pollution. Coal and oil were the main fuels used. The local authorities decided at that time to pay attention to particles and gases, carefully monitoring their levels in the air. Thus, very high levels of deposited particles and sulphates and not so high levels of total suspended particles (TSP) were registered; the maximal TSP concentration admitted daily being $150 \mu \mathrm{g} / \mathrm{m}^{3}$. After 1989, when the Revolution changed the economical system, a great part of the heavy industry was diminished, the industrial sources of air pollution became weaker, and the capacity of monitoring pollution decreased slowly but continuously. A good monitoring system was preserved at the Heavy Water Plant, and an alternative monitoring system was created, to investigate air pollution in the city (Environmental Protection Agency). Unfortunately, there were not created any conditions to establish the levels of $\mathrm{PM}_{10}$ (with mass median aerodynamic diameter - MMAD less than $10 \mu \mathrm{m}$ ), coarse particles or $\mathrm{PM}_{10-2.5}(\mathrm{MMAD}$ between 10 and $2.5 \mu \mathrm{m}$ ) and fine particles (MMAD of $2.5 \mu \mathrm{m}$ ) [Monn, 2001] yet. Observations of photochemical oxidants were performed only in special situations. Stationary air pollution sources diminished in importance, and traffic became a 
major one. Second hand cars released high concentrations of gases and particles. However, stationary points fixed near the industries or inside the city remained the main sites to monitor the air pollution in Drobeta Turnu-Severin.

The impact of air pollution on human health, especially on respiratory or cardiovascular systems, is well known. Many studies found significant association between air pollution and health effects (Abbey et al., 1999; Linn et al. 2000; Kelly et al., 2003). Particles proved to have a very complex structure (association between particles and gases was found) and they were measured in various ways. In literature, values between $30 \%$ and $90 \%$ are given for the share of $\mathrm{PM}_{10}$ (aerodynamic diameter less than $10 \mu \mathrm{m}$ ) in TSP (Total Suspended Particles) (Chen \& Mao, 1998; Fang et al., 1999). Air pollution with gases was considered as having a direct effect on health or was considered as an associated and confounding factor of air pollution with particles. This complexity and ubiquity of particles made them a major concern on human health.

The HEAPS (Health Effect of Air Pollution on Susceptible Population) study performed in Europe (Health Effect of Air Pollution on Susceptible Population [HEAPS], 2003) and the CESAR approach in Central Eastern Europe (Leonardi et al., 2002) offered and extended an accurate analysis of the effects of air pollution on health.

Respiratory diseases tend to increase in incidence and prevalence, but it was difficult to establish a relationship with air pollution due to the multi-factorial aetiology (Zielinski et al., 1997). People with chronic respiratory diseases especially Chronic Pulmonary Obstructive Diseases (COPD), Chronic Bronchitis (Chronic Bronchitis) and Asthma proved to be a susceptible sub-population exposed to air pollution (Dennis et al., 1996; Lindgren et al., 2009; Kurmi et al., 2010). Many studies analysed the existence of a connection between air pollution exposure and the aggravating or triggering of these chronic respiratory diseases in population (Wong et al., 1999). The young and the elderly were considered an especially vulnerable population (Ritz et al., 2009; Simoni et al., 2003).

Climate factors (temperature, humidity, and wind velocity or wind direction) also have an impact on chronic respiratory diseases. Variations of air temperature and humidity were demonstrated to be associated with asthma (Weiland et al., 2004). Acute accidents of air pollution happened in specific conditions of climate (Choukiker, 2005). Seasonality was demonstrated to be an important confounding factor on the relation air pollution - health. Increased variation of climate factors has a well-known direct influence on human health and on air pollution levels and variation to the same extent. Numerous present day studies demonstrate the variation of climate factors, the tendency of global warming, and its effects on human health and not only (Kowats et al., 1999; Van Vjingaarden \& Vincent, 2004).

Keeping in mind all additional factors that determine or aggravate respiratory pathology makes us more aware of the complexity of the relation between air pollution and health.

In the study performed, we aimed at examining long- and short-term respiratory health effects of air pollution with particles and gases in a vulnerable population group, and its modification due to climate parameters (air temperature and air humidity). Their changes in time were studied using a longitudinal retrospective inquiry and two time-series analyses of data, obtained in two successive periods and in the same area.

\section{Material and methods}

In order to assess the long and short-term effects of air pollution on chronic respiratory diseases and its modification by climate parameters we used the following material and methods. 


\subsection{Description of population and area under study}

Drobeta Turnu-Severin is a historic and industrial city situated in south-western Romania, on the north side of the Danube. Its population is about 100,000 inhabitants (Romanian Statistical Yearbook, 2006). This city used to be highly industrialized between 1970 and 1995, with an economical decrease afterwards. Heavy industry, a large carriage manufacturer, a paper plant, and numerous power plants polluted the environment intensively. The climate is temperate with Mediterranean influences. On the south-western side of the city there is a great accumulation lake built over the Danube and used by the Iron Gates Hydropower Plant. This accumulation lake changes the climate factors of the neighbouring area.

\subsection{Material}

The material consisted in studies on health, air pollution, and meteorological data.

\subsubsection{Health data}

Health data were provided by the County Hospital Drobeta Turnu-Severin. As we performed this study using two successive study periods, we used different data. In the first study period (1.01.1990-31.12.1997), we used incidence (number of new cases per 100,000 inhabitants) of COPD (ICD-10, J 44.0, 1, 8), of chronic bronchitis (ICD-10, J 41.0, 1, 8), and of asthma (ICD-10, J 45.0, 1, 8), counted in year of study and age groups, in the exposed population from Drobeta Turnu-Severin (study group), and 2 control groups from other urban and rural areas in Mehedinti County, representing the non-exposed population. Choosing diagnosed patients, we took into consideration the main definition of the three clinical endpoints.

In the second (1.01.2000-31.12.2003) study period, daily hospital admissions according to sex and age groups were recorded in the exposed area of Drobeta Turnu-Severin. During these two study periods, acute infectious respiratory disease cases were provided and used as a confounding factor.

\subsubsection{Air pollution data}

Air pollution data were provided by the Public Health Direction Mehedinti and comprised the maximum, minimum, and average daily concentration $\left(\mu \mathrm{g} / \mathrm{m}^{3}\right.$ air) of total suspended particles (TSP) for the two study-periods. The Environmental Protection Agency (EPA) Drobeta Turnu-Severin provided daily concentrations of SO2 and NO2 only for the period 23.01.2001 - 31.08.2002, included in the second study period. These pollutants were measured at 4 fixed sampling sites inside the city, 1 point being situated in a well known polluted area (near the Paper Plant). The measurements are based on the gravimetric method for TSP and automatic monitoring stations for $\mathrm{SO}_{2}$ and $\mathrm{NO}_{2}$.

\subsubsection{Meteorological data}

Meteorological data were provided by the Romanian Regional Meteorological Centre Craiova, Oltenia and comprised daily maximum, minimum, and average air temperature (Celsius degrees), relative air humidity $(\%)$, wind velocity $(\mathrm{m} / \mathrm{s})$ and wind direction. The meteorological station is situated in the western part of Drobeta Turnu-Severin. For the analysis of the second study period, we calculated the absolute humidity that gives the amount of water in air, using the relative humidity and the air temperature (Stull, 2000). 


\subsection{Methods}

A statistical analysis of all data gathered in the two study periods was performed.

\subsubsection{First study period}

A case-control study was performed for the relative risk of air pollution with particles (TSP) on respiratory health. For that purpose, three groups were considered: one populationgroup exposed to air pollution, and two control groups of non-exposed population, in other urban areas and the rural area of the region. Meteorological factors were considered as confounding factors. Spearman correlation was used to calculate associations of air pollution with TSP - meteorological factors and meteorological factors - respiratory health. Relative risk was measured considering the ratio of the exposed population with a specific chronic respiratory disease to the non-exposed population with a specific chronic respiratory disease. We considered relative risk taking into account an important confounding factor: different age and density distribution of population between urban and rural areas. Spearman's rank correlation coefficient assesses how well an arbitrary monotonic function can describe the relationship between two variables, without making any other assumption about the particular nature of the relationship between variables. The analysis based on rank correlations is insufficient, however, for days having zero hospital admissions due to respiratory ailments.

\subsubsection{Second study period}

Two time-series analyses were performed in the second study period in order to establish the short-term impact of air pollutants on health, one for TSP and the other considering gases: $\mathrm{NO}_{2}$ and $\mathrm{SO}_{2}$.

In the first time-series analysis, the Poisson regression, a method that belongs to the group of generalized linear models (GLM, Freeware R) was used to assess the risk. Missing TSP data were imputed by means of a special Kalman filter, which acts as a low pass for periods longer than 100 days. Absolute humidity was used, although relative humidity was recorded. The values of the current day and the values of the previous day (time lag effect) of the environmental factors were used considering a possible lagged influence on the hospital admissions. The adverse effect of TSP may be possibly modified by air temperature and/or air humidity. In the first time-series analysis, we used 2 approaches.

In the first approach, models of the following type were examined:

$$
\ln \left(\mu_{i}\right) \approx \beta_{o}+\beta_{1} \text { dow }_{i}+\beta_{2} \text { TSP }_{i}+\beta_{3} a_{b s H u m}+\beta_{4} \text { Tave }_{i}, i=1,2, \ldots, n,
$$

with $\mu_{\mathrm{i}}$ - the expected number of patients in day $\mathrm{i}$, dow $\mathrm{w}_{\mathrm{i}}$ - the day of the week and absHumi the absolute humidity.

In the second modelling approach, the annual variation was included. The variable "day" was introduced to represent the Julian day number and modelled with a spline (s):

$$
\ln \left(\mu_{i}\right) \approx \beta_{o}+\beta_{1} \text { dow }_{i}+\beta_{2} \text { TSP }_{i}+\beta_{3} a_{b s H u m_{i}}+\beta_{4} \text { Tave }_{i}+s(\text { day })
$$

Hospital admission data and risk factors follow seasonal variation. Generalized additive models (GAM - Hastie \& Tibshirani, 1987) and generalized linear models with natural splines were applied. All models were compared by the criterion AIC and explained deviance (the fraction of the deviance in the data explained by the model). 
In the second time-series analysis, we applied the additive models and the "Air Pollution and Health: a European Approach - 2" protocol (APHEA-2) (Atkinson et al., 2001). First, a core model without pollutants was built and, in the second stage, the core model was extended by air pollutants. Seasonal patterns and a dummy variable for the day of the week were always included and daily of mean, minimum and maximum air temperature and relative humidity as meteorological confounders were used as in the second study. Time delayed effects were moved up to seven days. Non-linear effects were modelled by thin plate regression splines with automatic smoothness selection by the mgcv-software-package (Wood, 2006). In the extended model, a PDLMs (Zanobetti et al., 2003) with a polynomial degree of three and a maximal lag effect of 10 were used for evaluation of the association and only for interpolated time-series. A threshold analysis was done for all significant effects of values greater than the threshold value, and all the concentration values below the threshold were set to zero. The modifying effect of air humidity for all observed adverse significant effects, including an interaction term (the product of the lagged effect of absolute humidity with the pollutant effect) in the model was investigated.

\section{Results obtained}

\subsection{First period study results}

\subsubsection{Descriptive statistics}

Chronic respiratory diseases (COPD, chronic bronchitis - $\mathrm{CB}$ and asthma) incidence in the exposed population (who live in Drobeta Turnu-Severin) was the following (Table 1), with a not so high mean of incidence for the entire first study period.

We registered an increased incidence of COPD in the third, fourth, and seventh years of the first study period, respectively in 1993 (330 cases/\%000 inhabitants), 1992 and 1996. Chronic bronchitis incidence was increased in the years 1993 (253 cases/\%00 inhabitants) and 1996, and asthma incidence was increased in the same years, and 1997 (with the highest value - 74 cases $/ \%{ }_{000}$ inhabitants).

\begin{tabular}{|c|c|c|c|c|c|c|c|c|c|}
\hline \multirow{2}{*}{$\begin{array}{c}\text { Respiratory } \\
\text { diseases }\end{array}$} & \multicolumn{7}{|c|}{ Years of first study } & \multirow{2}{*}{ Mean } \\
\cline { 2 - 10 } & 1 & 2 & 3 & 4 & 5 & 6 & 7 & 8 & \\
\hline COPD & 61 & 74 & $\mathbf{1 5 5}$ & $\mathbf{3 3 0}$ & 181 & 172 & $\mathbf{2 6 3}$ & $\mathbf{1 7 3}$ & 176 \\
\hline CB & 43 & 49 & 116 & $\mathbf{2 5 3}$ & 140 & 114 & $\mathbf{1 8 5}$ & 81 & 122 \\
\hline Asthma & 10 & 16 & 30 & $\mathbf{5 3}$ & 36 & 46 & $\mathbf{5 9}$ & $\mathbf{7 4}$ & 40 \\
\hline
\end{tabular}

Table 1. Distribution of chronic respiratory diseases (COPD, CB and asthma) incidence (cases $/ \%_{000}$ inhabitants) in the exposed population (Drobeta Turnu-Severin) during the first study period

Distribution of chronic respiratory diseases incidence according to age groups proved to be very different, with the highest values in the age group 15-64 years for COPD and CB, and in the age's group 1-14 years for asthma (Table 2).

Chronic respiratory diseases (COPD, chronic bronchitis - $\mathrm{CB}$ and asthma) incidence in the $\mathbf{1}^{\text {st }}$ control group (other urban areas) can be seen in Table 3.

Age group distribution of incidence in the $1^{\text {st }}$ control group (other urban areas) can be seen in Table 4. 


\begin{tabular}{|c|c|c|c|}
\hline \multirow{2}{*}{$\begin{array}{c}\text { Respiratory } \\
\text { diseases }\end{array}$} & \multicolumn{3}{|c|}{$\begin{array}{c}\text { Incidences on age groups } \\
\text { (years) }\end{array}$} \\
\cline { 2 - 4 } & $1-14$ & $15-64$ & $>65$ \\
\hline COPD & 165 & $\mathbf{7 2 0}$ & 524 \\
\hline CB & 6 & $\mathbf{5 3 2}$ & 445 \\
\hline Asthma & $\mathbf{1 5 9}$ & 130 & 35 \\
\hline
\end{tabular}

Table 2. Distribution of chronic respiratory diseases (COPD, CB and asthma) incidence (cases/\%000 inhabitants) in the exposed population (Drobeta Turnu-Severin) depending on age groups, in the first study period

\begin{tabular}{|c|c|c|c|c|c|c|c|c|c|}
\hline \multirow{2}{*}{$\begin{array}{c}\text { Respiratory } \\
\text { diseases }\end{array}$} & \multicolumn{7}{|c|}{ Years of first study } & \multirow{2}{*}{ Mean } \\
\cline { 2 - 10 } & 1 & 2 & 3 & 4 & 5 & 6 & 7 & 8 & \\
\hline COPD & 188 & 75 & 71 & 14 & 286 & 70 & 299 & 101 & 138 \\
\hline CB & 122 & 75 & 64 & 14 & 56 & 40 & 257 & 37 & 83 \\
\hline Asthma & 66 & 0 & 7 & 0 & 230 & 30 & 42 & 62 & 54 \\
\hline
\end{tabular}

Table 3. Distribution of chronic respiratory diseases (COPD, CB and asthma) incidences (cases/\%000 inhabitants) in the $1^{\text {st }}$ control group (other urban areas) during the first study period

\begin{tabular}{|c|c|c|c|}
\hline \multirow{2}{*}{$\begin{array}{c}\text { Respiratory } \\
\text { diseases }\end{array}$} & \multicolumn{3}{|c|}{$\begin{array}{c}\text { Incidence according to age groups } \\
\text { (years) }\end{array}$} \\
\cline { 2 - 4 } & $1-14$ & $15-64$ & $>65$ \\
\hline COPD & 253 & 351 & 498 \\
\hline CB & 37 & 168 & 460 \\
\hline Asthma & 216 & 183 & 38 \\
\hline
\end{tabular}

Table 4. Distribution of chronic respiratory diseases (COPD, CB and asthma) incidence (cases/\% $\% 00$ inhabitants) in the $1^{\text {st }}$ control group (other urban areas) depending on age group, in the first study period

Chronic respiratory diseases (COPD, chronic bronchitis - $\mathrm{CB}$ and asthma) incidence in the $2^{\text {nd }}$ control group (rural areas) can be seen in Table 5 .

\begin{tabular}{|c|c|c|c|c|c|c|c|c|c|}
\hline \multirow{2}{*}{$\begin{array}{c}\text { Respiratory } \\
\text { diseases }\end{array}$} & \multicolumn{7}{|c|}{ Years of first study } & \multirow{2}{*}{ Mean } \\
\cline { 2 - 10 } & 1 & 2 & 3 & 4 & 5 & 6 & 7 & 8 & \\
\hline COPD & 139 & 198 & 154 & 116 & 123 & 261 & 174 & 143 & 164 \\
\hline CB & 92 & 185 & 123 & 78 & 92 & 202 & 134 & 107 & 126 \\
\hline Asthma & 22 & 12 & 21 & 20 & 22 & 29 & 27 & 32 & 23 \\
\hline
\end{tabular}

Table 5. Distribution of chronic respiratory diseases (COPD, CB and asthma) incidence (cases $/ \% 000$ inhabitants) in the $2^{\text {nd }}$ control group (rural areas) during the first study period 
Age groups distribution of incidences in the $2^{\text {nd }}$ control group (rural areas) can be seen in Table 6.

\begin{tabular}{|c|c|c|c|}
\hline \multirow{2}{*}{$\begin{array}{c}\text { Respiratory } \\
\text { diseases }\end{array}$} & \multicolumn{3}{|c|}{$\begin{array}{c}\text { Incidences on age groups } \\
\text { (years) }\end{array}$} \\
\cline { 2 - 4 } & $1-14$ & $15-64$ & $>65$ \\
\hline COPD & 63 & 798 & 452 \\
\hline CB & 37 & 616 & 360 \\
\hline Asthma & 25 & 119 & 42 \\
\hline
\end{tabular}

Table 6. Distribution of chronic respiratory diseases (COPD, CB, and asthma) incidence (cases/\% $\%$ inhabitants) in the $2^{\text {nd }}$ control group (rural areas) depending on age group, in the first study period

We noticed large variation of chronic respiratory diseases incidence depending on the area and age group.

In the first study period (1.01.1990-31.12.1997) we registered the following levels of air pollution with TSP considering the mean, the maximum and minimum values, measured yearly and for the entire first study period (Table 7).

\begin{tabular}{|c|c|c|c|c|c|c|c|c|c|c|c|}
\hline \multirow{2}{*}{ TSP } & \multicolumn{7}{|c|}{ Years of first study } & \multirow{2}{*}{ Mean } & \multirow{2}{*}{ Median } & \multirow{2}{*}{ SD } \\
\cline { 2 - 12 } & 1 & 2 & 3 & 4 & 5 & 6 & 7 & 8 & & & \\
\hline M & 189 & 104 & 71 & 129 & 137 & 161 & 174 & 110 & $\mathbf{1 3 4}$ & 133 & 39 \\
\hline Max & 440 & 270 & 120 & 80 & 330 & 360 & 330 & 270 & 275 & 300 & 121 \\
\hline Min & 50 & 40 & 30 & 2 & 40 & 20 & 60 & 30 & 34 & 35 & 17 \\
\hline
\end{tabular}

Table 7. Yearly distribution of TSP values $\left(\mu \mathrm{g} / \mathrm{m}^{3}\right.$ air $)$ in the first study period

\begin{tabular}{|c|c|c|c|c|c|c|c|c|c|c|c|}
\hline \multirow{2}{*}{ Season } & \multicolumn{7}{|c|}{ Years of first study } & \multirow{2}{*}{ Mean } & Median & $\begin{array}{c}\text { Standard } \\
\text { deviation }\end{array}$ \\
\cline { 2 - 12 } & 1 & 2 & 3 & 4 & 5 & 6 & 7 & 8 & & & 42 \\
\hline Winter & 175 & 167 & 71 & 80 & 168 & 161 & 165 & 164 & 143 & $\mathbf{1 6 4}$ & 35 \\
\hline Spring & 171 & 141 & 70 & 105 & 101 & 143 & 162 & 096 & 123 & 123 & 61 \\
\hline Summer & 194 & 93 & - & 131 & 132 & 167 & 174 & 93 & 123 & 131 & 71 \\
\hline Autumn & 217 & 88 & - & 163 & 138 & 176 & 203 & 96 & 135 & $\mathbf{1 5 0}$ & \\
\hline
\end{tabular}

Table 8. Seasonal distribution of TSP values $\left(\mu \mathrm{g} / \mathrm{m}^{3}\right.$ air) in the first study period

The annual means and entire study mean exceeds the maximum admitted concentration in United States for TSP $\left(75 \mu \mathrm{g} / \mathrm{m}^{3}\right.$ air) or maximum admitted concentration for PM10 in Europe $\left(40 \mu \mathrm{g} / \mathrm{m}^{3}\right.$ air $)$.

Air pollution with particles (TSP) was also analysed depending on season, for each year and for entire first study period (Table 8).

The season means and medians calculated in each year of the first study and for the total study period indicate frequent surpassing of the annual maximum admitted concentration 
for TSP and even daily maximum admitted concentration of TSP $\left(150 \mu \mathrm{g} / \mathrm{m}^{3}\right.$ air $)$ in winter and autumn. A possible explanation of increased air pollution in these seasons could be the use of heat sources based on burning fuel.

Climate factors measured yearly and for the entire first study period (Table 9) revealed high relative humidity in the area (over $70 \%$ ), temperature higher than 10 Celsius degrees and low wind velocity $(1.97 \mathrm{~m} / \mathrm{s})$. Wind direction was North/North-West.

\begin{tabular}{|c|c|c|c|c|c|c|c|c|c|}
\hline \multirow{2}{*}{$\begin{array}{c}\text { Climate } \\
\text { factors }\end{array}$} & \multicolumn{7}{|c|}{ Years of first study } & \multirow{2}{*}{ Mean } \\
\cline { 2 - 10 }$n$ & 1 & 2 & 3 & 4 & 5 & 6 & 7 & 8 & \\
\hline $\mathrm{T}\left({ }^{\circ} \mathrm{C}\right)$ & 12.50 & 10.65 & 12.50 & 11.78 & 12.92 & 11.53 & 11.46 & 11.24 & $\mathbf{1 1 . 8 2}$ \\
\hline $\mathrm{Hu}(\%)$ & 75.66 & 80.58 & 72.50 & 74.25 & 75.50 & 74.33 & 74.25 & 71.00 & $\mathbf{7 4 . 7 5}$ \\
\hline w.v $(\mathrm{m} / \mathrm{s})$ & 2.00 & 1.96 & 2.19 & 2.22 & 1.95 & 1.81 & 1.85 & 1.85 & $\mathbf{1 . 9 7}$ \\
\hline
\end{tabular}

Table 9. Yearly mean values of climate factors in the first study period

The seasonal evolution of climate factors (Table 10) indicates that the highest value of temperature was registered in summer $\left(21.63^{\circ} \mathrm{C}\right)$ and the lowest in winter $\left(3.03{ }^{\circ} \mathrm{C}\right)$, the highest relative humidity in autumn $(82.29 \%)$ and the lowest in summer $(68.83 \%)$, the highest wind velocity in winter $(2.22 \mathrm{~m} / \mathrm{s})$ and the lowest in autumn $(1.65 \mathrm{~m} / \mathrm{s})$. We noticed that in winter there was low temperature, high relative humidity $(78.24 \%)$ and increased wind velocity. The investigated area is situated near the Danube and not far from an accumulation lake built on the Danube: the Iron Gates Hydropower plant, fact that explains increased air humidity in all seasons (over 65\%).

\begin{tabular}{|c|c|c|c|c|c|}
\hline \multirow{2}{*}{$\begin{array}{c}\text { Climate } \\
\text { factors }\end{array}$} & \multicolumn{4}{|c|}{ Seasons } & \multirow{2}{*}{ Mean } \\
\cline { 2 - 5 } & Winter & Spring & Summer & Autumn & \\
\hline $\mathrm{T}(\mathrm{o} \mathrm{C})$ & $\mathbf{3 . 0 3}$ & 16.59 & $\mathbf{2 1 . 6 3}$ & 6.20 & 11.82 \\
\hline $\mathrm{Hu}(\%)$ & $\mathbf{7 8 . 2 4}$ & 70.49 & $\mathbf{6 8 . 8 3}$ & $\mathbf{8 2 . 2 9}$ & $\mathbf{7 4 . 7 5}$ \\
\hline $\mathrm{w} . \mathrm{v}(\mathrm{m} / \mathrm{s})$ & $\mathbf{2 . 2 2}$ & 2.06 & $\mathbf{2 . 0 3}$ & 1.65 & 1.97 \\
\hline
\end{tabular}

Table 10. Seasonal mean values of climate factors in the first study period

\subsubsection{Relative risk}

A significant relative risk of TSP was found for COPD in exposed population in comparison with the $1^{\text {st }}$ control group (other urban areas) and the $2^{\text {nd }}$ control group (rural areas, see Figure 1).

The relative risk of TSP on chronic respiratory diseases in the exposed population measured in comparison with the non-exposed populations ( $1^{\text {st }}$ and $2^{\text {nd }}$ control groups) presented as main confounding factors different age group distribution and density of population between urban and rural areas. We excluded the differences between the two control groups comparing them. We considered the registered differences when we measured the relative risk for exposed population considering the $2^{\text {nd }}$ control group (rural area). The registered values for the measured relative risk of TSP on chronic respiratory diseases (COPD, CB, asthma) can be seen in Tables 11 and 12 . 

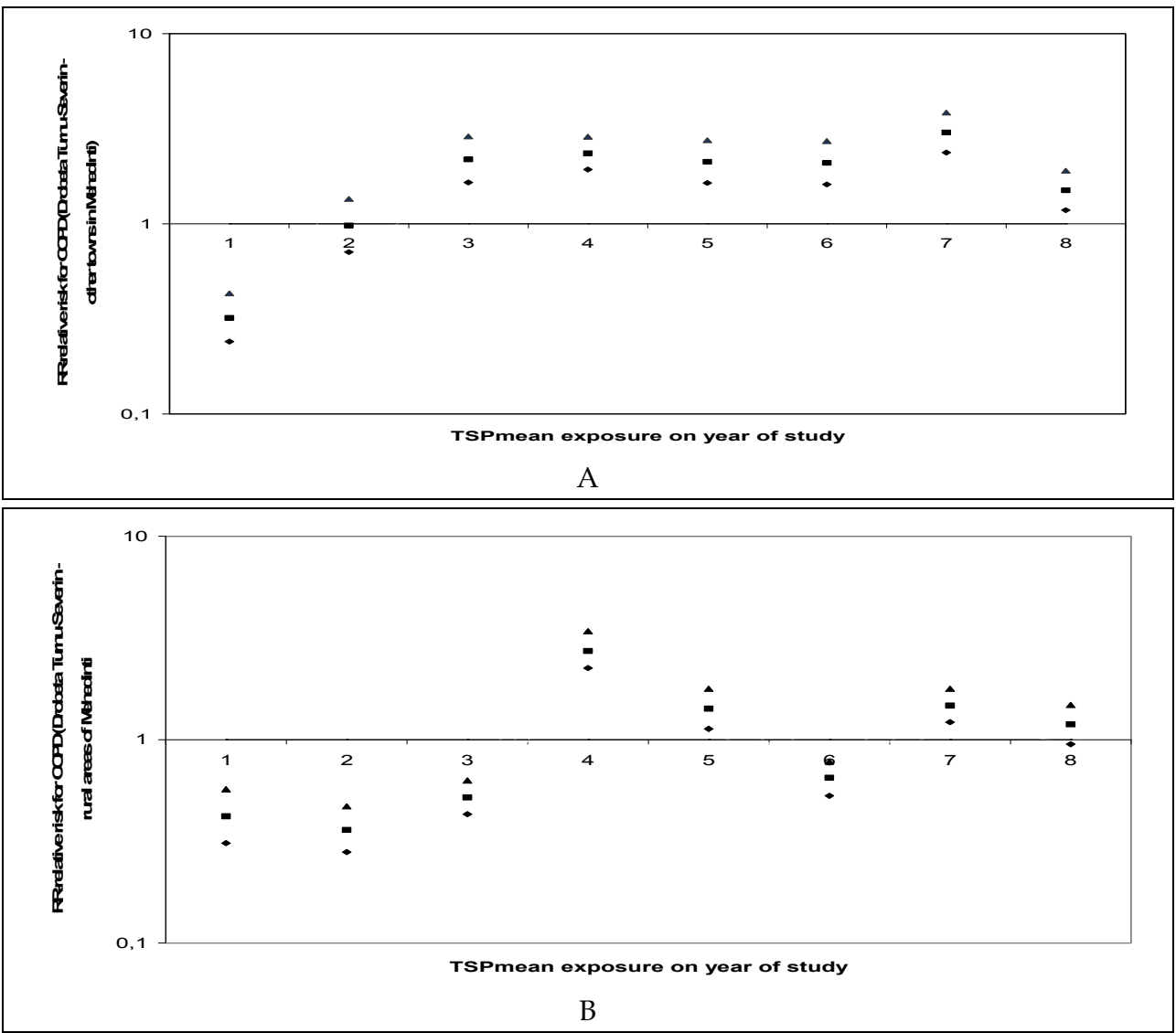

Fig. 1. Relative risk (RR) values for COPD in the population exposed to TSP related to the 1st control group - other urban areas (A) and the 2nd control group - rural area (B)

\begin{tabular}{|c|c|c|c|}
\hline \multirow{2}{*}{ Chronic respiratory diseases } & \multicolumn{3}{|c|}{ Relative risk according to age group } \\
\cline { 2 - 4 } & $1-14$ years & $15-64$ years & $>$ 65 years \\
\hline COPD (RR) & 0.65 & $\mathbf{2 . 0 5}$ & $\mathbf{1 . 0 5}$ \\
CI & $0.53-0.79$ & $1.8-2.32$ & $0.93-1.18$ \\
\hline CB (RR) & 0.16 & $\mathbf{3 . 1 6}$ & 0.96 \\
CI & $0.07-0.37$ & $2.66-3.76$ & $0.85-1.09$ \\
\hline Asthma (RR) & 0.73 & 0.71 & 0.92 \\
CI & $0.6-0.9$ & $0.56-0.88$ & $0.58-1.45$ \\
\hline
\end{tabular}

Confidence interval Nurminen-Miettinen

Table 11. Relative risk of TSP on chronic respiratory diseases considering age groups and 1st control group (other urban areas) 
There is an observable increase in the relative risk of TSP on chronic bronchitis in the age group 15-64 years and on COPD in the age groups 16-64 years and over 65 years, and in the exposed population as compared to non-exposed population from other urban areas.

\begin{tabular}{|c|c|c|c|}
\hline \multirow{2}{*}{ Chronic respiratory diseases } & \multicolumn{3}{|c|}{ Relative risk according to age groups } \\
\cline { 2 - 4 } & $1-14$ years & $15-64$ years & $>$ 65 years \\
\hline COPD (RR) & 0.65 & $\mathbf{2 . 0 8}$ & $\mathbf{2 . 9 4}$ \\
CI & $0.64-0.66$ & $2.02-2.12$ & $2.94-2.95$ \\
\hline CB (RR) & 0.15 & $\mathbf{3 . 1 8}$ & 0.96 \\
CI & $0.1-0.23$ & $3.03-3.44$ & $0.96-0.97$ \\
\hline Asthma (RR) & 0.73 & 0.71 & 0.89 \\
CI & $0.73-0.74$ & $0.69-0.72$ & $0.75-1.04$ \\
\hline
\end{tabular}

Confidence interval Nurminen-Miettinen

Table 12. Relative risk of TSP on chronic respiratory diseases considering age group and $2^{\text {nd }}$ control group (rural areas) with exclusion of confounding factors between urban and rural areas

Comparing the exposed with the non-exposed population from rural areas, after excluding the differences urban - rural, we noticed the same increased risk of TSP on chronic bronchitis in the age group 15-64 years and on COPD in the age groups over 65 years and 15-64 years.

\subsubsection{Spearman correlation of variables}

We applied the following Spearman correlations: chronic respiratory diseases - air pollution with TSP, air pollution with TSP - climate factors, and chronic respiratory diseases - climate factors. Significant results were obtained only for the Spearman correlation asthma relative air humidity (Table 13).

\begin{tabular}{|c|c|c|}
\hline & & $\begin{array}{c}\text { Asthma incidence } \\
\text { 15-64 years }\end{array}$ \\
\hline Relative air humidity (\%) & rho & $\mathbf{- 0 8 5 0 * *}$ \\
\hline CI & p value & 0.007 \\
\hline
\end{tabular}

${ }^{* *}$ Correlation is significant at 0.01 level (2-tailed)

Table 13. Spearman correlation (rho) asthma incidence - relative air humidity

This result indicates a protective effect of elevated air humidity on asthma, especially in the age group 15-64 years.

\subsection{Second period study results}

\subsubsection{Descriptive statistics}

Descriptive analysis performed in the second study period (1.01.2000-31.12.2003) can be seen in Table 14. The values for all variables were available for 1461 days, but for TSP only for 820 days. The patients were classified according to sex. 


\begin{tabular}{|c|c|c|c|c|c|c|c|}
\hline & Minimum & $\begin{array}{c}\text { First } \\
\text { quartile }\end{array}$ & Average & Median & $\begin{array}{c}\text { Third } \\
\text { quartile }\end{array}$ & Maximum & $\begin{array}{c}\text { Standard } \\
\text { Error }\end{array}$ \\
\hline COPDm (cases) & 0 & 0 & 0.91 & 1 & 1 & 7 & 1.17 \\
\hline COPDf & 0 & 0 & 0.43 & 0 & 1 & 4 & 0.70 \\
\hline CBm & 0 & 0 & 0.21 & 0 & 0 & 4 & 0.48 \\
\hline CBf & 0 & 0 & 0.16 & 0 & 0 & 3 & 0.41 \\
\hline Asthma m & 0 & 0 & 0.24 & 0 & 0 & 4 & 0.52 \\
\hline Asthma f & 0 & 0 & 0.46 & 0 & 1 & 5 & 0.80 \\
\hline TSP $\left(\mu \mathrm{g} / \mathrm{m}^{3}\right.$ air $)$ & 18 & 75 & 111.42 & 105 & 142 & 289 & 47.39 \\
\hline T min & -14 & 1 & 7.78 & 8.2 & 14.7 & 25.8 & 8.22 \\
\hline Tave $\left({ }^{\circ} \mathrm{C}\right)$ & -9.2 & 5.1 & 12.78 & 12.8 & 20.8 & 31.7 & 9.42 \\
\hline Tmax & -6 & 9.6 & 18.61 & 19.4 & 27.6 & 42.6 & 10.9 \\
\hline Rel. hu $(\%)$ & 29 & 58 & 67.96 & 68 & 79 & 100 & 14.55 \\
\hline w.v. $(\mathrm{m} / \mathrm{s})$ & 0 & 3 & 5.64 & 5 & 8 & 16 & 3.18 \\
\hline
\end{tabular}

m-male, f-female

Table 14. Descriptive analysis in the second study period

We realised that the day of the week (dow) is an important confounding factor (Figure 2).

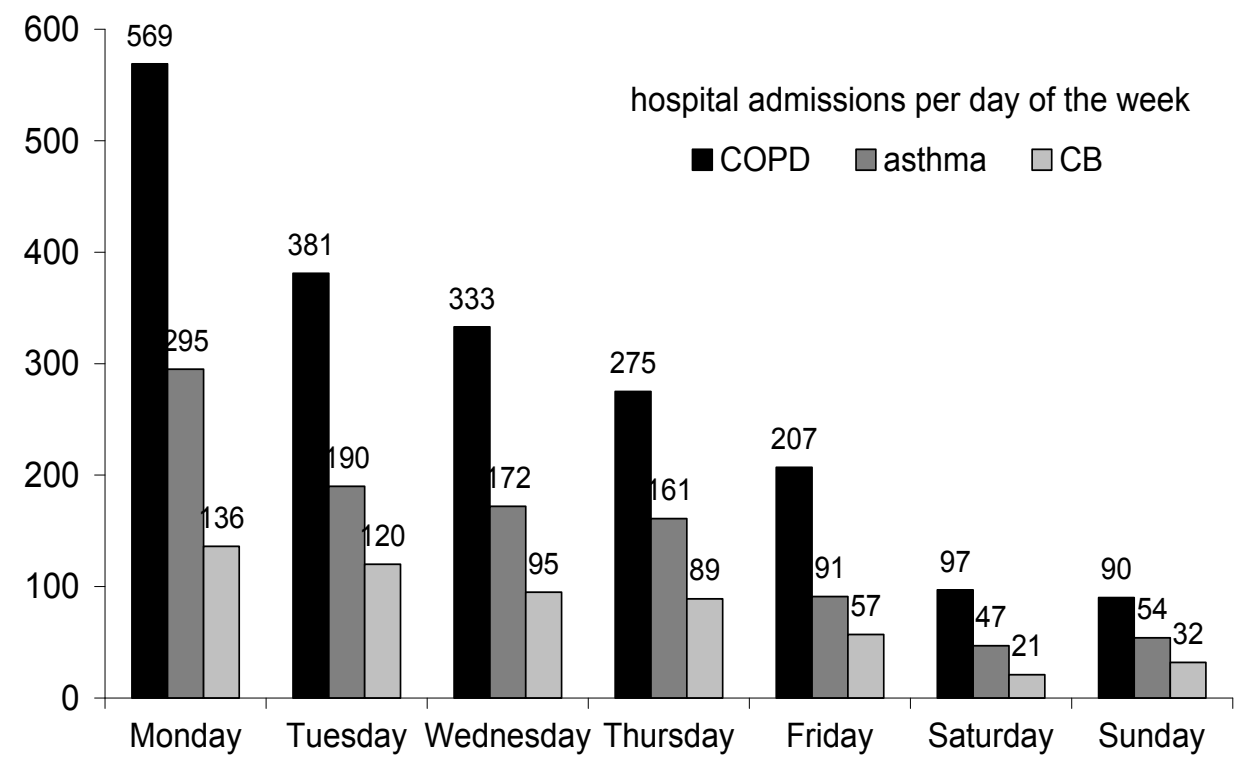

Fig. 2. Number of patients with chronic respiratory diseases for each day of the week 
The number of patients is maximal on Monday and minimal on Sunday. One explanation could be the admission of patients on Monday and the discharge from hospital on Friday. The average period of hospitalisation of a patient is 5 days.

\subsubsection{Risk evaluation - first time-series analysis results}

\section{COPD (Chronic Obstructive Pulmonary Diseases)}

In the first approach (Table 15), a protective effect of absolute humidity on COPD (abs Hum coeff. $=-0.0347$ ) was noticed. The protective effect of air humidity was modified by TSP (abs Hum: TSP $=-0.0011)$. The relative risk of this modification was rather small with low statistical significance $(R R=\exp (0.001) \sim 1.001, p=0.008)$.

\begin{tabular}{|l|l|l|l|}
\hline Variable 1 & Coefficient & s.e. & P value \\
\hline Intercept & 1.1870 & 0.0640 & $<0.0001$ \\
\hline Tuesday & -0.4496 & 0.0670 & $<0.0001$ \\
\hline Wednesday & -0.5425 & 0.0693 & $<0.0001$ \\
\hline Thursday & -0.7590 & 0.0743 & $<0.0001$ \\
\hline Friday & -0.9780 & 0.0803 & $<0.0001$ \\
\hline Saturday & -1.7410 & 0.1084 & $<0.0001$ \\
\hline Sunday & -1.8440 & 0.1134 & $<0.0001$ \\
\hline absHum & -0.0347 & 0.0088 & $<0.0001$ \\
\hline absHum:TSP & 0.0011 & 0.0006 & 0.0833 \\
\hline
\end{tabular}

Table 15. Results of the first model approach for COPD

This change of the humidity effect suggested a high influence of the season on respiratory diseases (especially COPD), the annual trend, and temperature being involved.

\section{The second approach}

The yearly variation and the effect of temperature were modelled with a spline. The absolute humidity has a significant adverse effect on the age group 18-44 years. A positive difference between absolute humidity of the current and preceding day increases the risk in three age groups (Table 16).

The absolute humidity varies direct proportionally with the number of admitted patients in the hospital. A significant influence of TSP was not observed. The spline function of seasonality has local minima in summer and local maxima in winter. If the function becomes 0 , there is no influence on the expected number of hospital admissions. The function has positive values in winter and this indicates an increased risk on hospital admissions, the negative one is in summer and the risk is reduced. 


\begin{tabular}{|c|c|c|c|c|}
\hline Variable 1 & Coefficient & s.e. & P value & RR \\
\hline Intercept & -2.9672 & 0.2133 & $<0.0001$ & - \\
\hline Tuesday & -0.4002 & 0.0480 & $<0.0001$ & 0.6702 \\
\hline Wednesday & -0.5390 & 0.0500 & $<0.0001$ & 0.5833 \\
\hline Thursday & -0.7336 & 0.0533 & $<0.0001$ & 0.4802 \\
\hline Friday & -1.0021 & 0.0588 & $<0.0001$ & 0.3671 \\
\hline Saturday & -1.7597 & 0.0795 & $<0.0001$ & 0.1721 \\
\hline Sunday & -1.8520 & 0.0821 & $<0.0001$ & 0.1569 \\
\hline absHum 18-44 & $\mathbf{0 . 0 6 0 0}$ & 0.0229 & 0.0088 & $\mathbf{1 . 0 6 1 9}$ \\
\hline Dif absHum 18-44 & $\mathbf{0 . 1 3 5 2}$ & 0.0682 & 0.0473 & $\mathbf{1 . 1 4 4 8}$ \\
\hline Dif absHum 45-64 & $\mathbf{0 . 0 6 4 5}$ & 0.0221 & 0.0035 & $\mathbf{1 . 0 6 6 7}$ \\
\hline Dif absHum 65-74 & $\mathbf{0 . 0 6 5 3}$ & 0.0262 & 0.0126 & $\mathbf{1 . 0 6 7 8}$ \\
\hline
\end{tabular}

Table 16. Results of the second model approach for COPD

\section{Chronic Bronchitis}

In the first approach, we did not find a significant effect of TSP on chronic bronchitis. The absolute humidity has a protective effect at very high value (more than $6 \mathrm{~g} / \mathrm{m}^{3}$ air).

In the second approach, we found a TSP risk on chronic bronchitis and a protective effect of absolute humidity on the same disease (Table 17).

\begin{tabular}{|c|c|c|c|c|}
\hline Variable 1 & Coefficient & s.e. & P value & RR \\
\hline Intercept & -1.3895 & 0.1754 & $<0.0001$ & - \\
\hline Tuesday & -0.1534 & 0.0643 & 0.0170 & 0.8578 \\
\hline Wednesday & -0.3731 & 0.0684 & $<0.0001$ & 0.6886 \\
\hline Thursday & -0.4016 & 0.0698 & $<0.0001$ & 0.6692 \\
\hline Friday & -0.8759 & 0.0806 & $<0.0001$ & 0.4165 \\
\hline Saturday & -1.8801 & 0.1196 & $<0.0001$ & 0.1526 \\
\hline Sunday & -1.4482 & 0.1002 & $<0.0001$ & 0.2350 \\
\hline TSP lag 1 18-44 & $\mathbf{0 . 0 0 7 1}$ & 0.0015 & $<0.0001$ & $\mathbf{1 . 0 0 7 1}$ \\
\hline absHum & $\mathbf{- 0 . 0 6 4 8}$ & 0.0171 & $<0.0001$ & $\mathbf{0 . 9 3 7 2}$ \\
\hline
\end{tabular}

Table 17. Results of second model approach for chronic bronchitis 


\section{Asthma}

In the first approach (Table 18), TSP had an adverse effect on asthma.

\begin{tabular}{|c|c|c|c|}
\hline Variable 1 & Coefficient & s.e. & P value \\
\hline Intercept & 0.3169 & 0.1053 & 0.0026 \\
\hline Tuesday & -0.3226 & 0.0911 & 0.0004 \\
\hline Wednesday & -0.5215 & 0.0972 & $<0.0001$ \\
\hline Thursday & -0.5972 & 0.0993 & $<0.0001$ \\
\hline Friday & -1.1167 & 0.1194 & $<0.0001$ \\
\hline Saturday & -1.7127 & 0.1507 & $<0.0001$ \\
\hline Sunday & -1.7060 & 0.1507 & $<0.0001$ \\
\hline TSP & $\mathbf{0 . 0 1 6 7}$ & 0.00836 & 0.0453 \\
\hline absHum:TSP & $\mathbf{- 0 . 0 0 2 2}$ & 0.00073 & 0.0023 \\
\hline
\end{tabular}

Table 18. Results of first model approach for asthma

\begin{tabular}{|c|c|c|c|c|}
\hline Variable 1 & Coefficient & s.e. & P value & RR \\
\hline Intercept & -1.9800 & 0.1986 & $<0.0001$ & - \\
\hline Tuesday & -0.4420 & 0.0562 & $<0.0001$ & 0.6427 \\
\hline Wednesday & -0.5402 & 0.0578 & $<0.0001$ & 0.5826 \\
\hline Thursday & -0.6037 & 0.0592 & $<0.0001$ & 0.5468 \\
\hline Friday & -1.1739 & 0.0722 & $<0.0001$ & 0.3092 \\
\hline Saturday & -1.8348 & 0.0945 & $<0.0001$ & 0.1596 \\
\hline Sunday & -1.6989 & 0.0890 & $<0.0001$ & 0.1829 \\
\hline TSP lag 1 0-17 & $\mathbf{0 . 0 0 6 8}$ & 0.0014 & $<0.0001$ & 1.0068 \\
\hline absHum 45-65 & $\mathbf{- 0 . 0 3 4 1}$ & 0.0149 & 0.0222 & 0.9665 \\
\hline absHum >66 & $\mathbf{- 0 . 0 4 6 3}$ & 0.0227 & 0.0412 & 0.9548 \\
\hline
\end{tabular}

Table 19. Results of second model approach for asthma 
Absolute humidity modified this effect and was protective. The relative risk of this modification was $\exp (-0.0022) \sim 0.008$, for a fixed TSP value and a rise of $1 \mathrm{~g}$ water $/ \mathrm{m}^{3}$. In the second approach, TSP has an adverse effect on asthma in age group 0-17 years. Absolute humidity has a protective effect on asthma in older people (Table 19).

\subsubsection{Descriptive statistics - considering gases}

TSP, gases $\left(\mathrm{NO}_{2}\right.$ and $\left.\mathrm{SO}_{2}\right)$, number of cases of chronic respiratory diseases and climate factors were analysed during the time interval 23.01.2001 - 31.08.2002 (Table 20) in the second study period.

\begin{tabular}{|c|c|c|c|c|c|c|c|}
\hline & $\begin{array}{c}\text { Mis } \\
\text { sing } \\
(\%)\end{array}$ & $\begin{array}{c}\text { Cases/ } \\
\text { year }\end{array}$ & Mean & Median & Minim & Maxim & $\begin{array}{l}\text { Standard } \\
\text { Deviation }\end{array}$ \\
\hline COPD (cases) & 0 & 511 & 1.4 & 1 & 0 & 10 & 1.55 \\
\hline CB (cases) & 0 & 160 & 0.44 & 0 & 0 & 3 & 0.71 \\
\hline Asthma (cases) & 0 & 282 & 0.77 & 0 & 0 & 7 & 1.08 \\
\hline $\mathrm{TSP}\left(\mu \mathrm{g} / \mathrm{m}^{3}\right.$ air $)$ & 42 & - & 123.4 & 122 & 22 & 289 & 44.12 \\
\hline $\mathrm{SO} 2\left(\mu \mathrm{g} / \mathrm{m}^{3}\right.$ air $)$ & 16 & - & 4.68 & 4,6 & 1.7 & 10.4 & 1.55 \\
\hline NO2 ( $\mu \mathrm{g} / \mathrm{m}^{3}$ air $)$ & 16 & - & 11.8 & 11 & 1 & 33.5 & 3.84 \\
\hline T high $\left({ }^{\circ} \mathrm{C}\right)$ & 0 & - & 20.23 & 21.5 & -4 & 39.5 & 10.08 \\
\hline Tmean $\left({ }^{\circ} \mathrm{C}\right)$ & 0 & - & 14.06 & 14.9 & -8.2 & 31.7 & 9.03 \\
\hline Tlow $\left({ }^{\circ} \mathrm{C}\right)$ & 0 & - & 8.81 & 9.6 & -13.2 & 25.8 & 8.19 \\
\hline Rel. hu (\%) & 0 & - & 67.76 & 68 & 29 & 98 & 13.93 \\
\hline $\operatorname{AbsHum}\left(\mathrm{g} / \mathrm{m}^{3}\right)$ & 0 & - & 8.79 & 8.23 & 2.05 & 19.2 & 4.03 \\
\hline
\end{tabular}

Table 20. Descriptive analysis during the interval 23.01.2001 - 31.08.2002 in the second study period

Hospital admissions showed a weekly and a seasonal cycle. The maximum of average hospital admissions occurred on Monday and the minimum on Sunday (Figure 3) during this time interval, this result being similar with the situation of the second study period. Moreover, in this time interval we studied the seasonal variation. The maximum average monthly admission was in January and the minimum in August for COPD and asthma, and September for chronic bronchitis (Figure 4). 


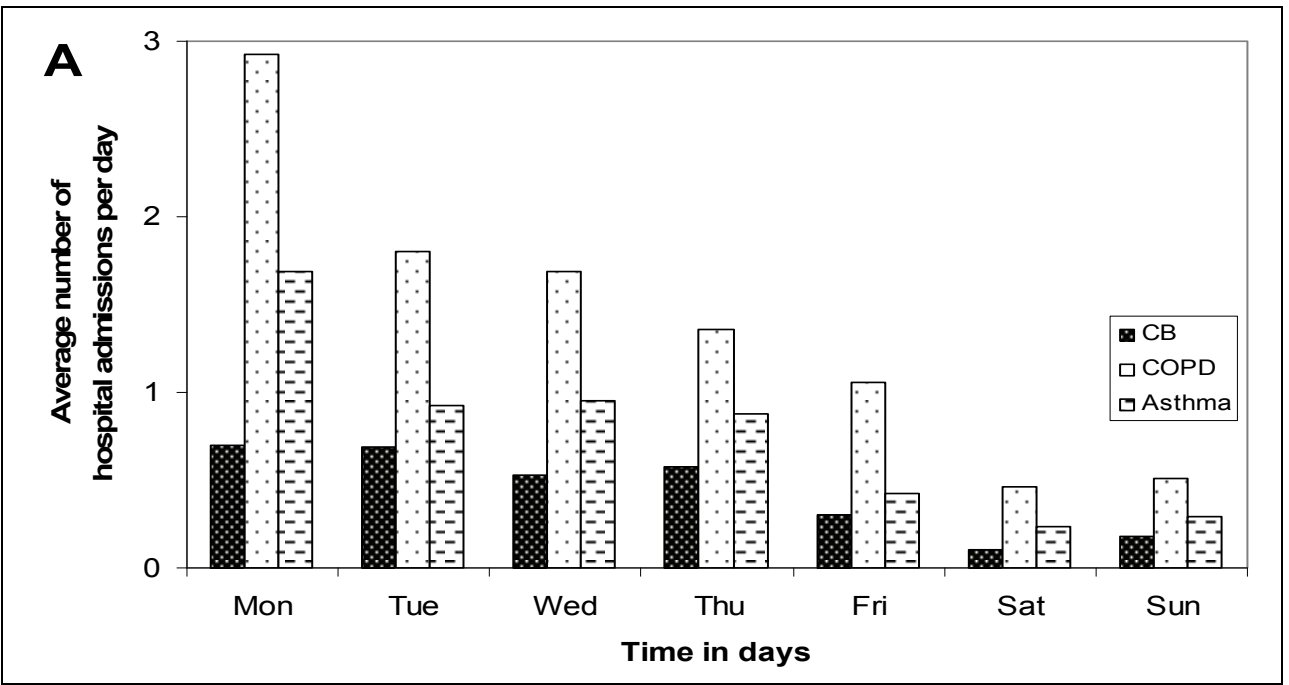

Fig. 3. The weekly cycle of daily hospital admission

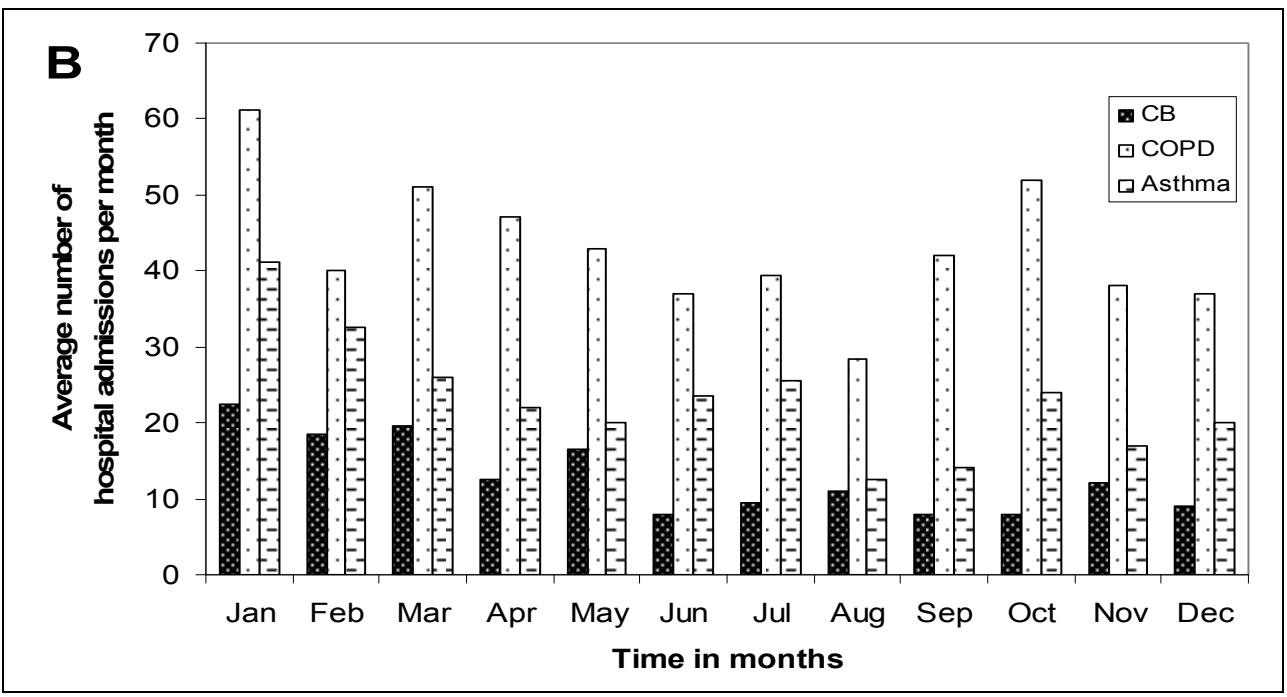

Fig. 4. The seasonal cycle of monthly hospital admission

\subsubsection{Risk evaluation - second time-series analysis results considering gases}

\section{Effects of TSP on chronic bronchitis}

Significant results of applying this model were found only for chronic bronchitis.

The core model for chronic bronchitis consisted of factor variables for workdays/holidays and nonlinear effects of time, of temperature with a lag of 6 days, of change of humidity over the last three days. 
For the single lag model, an increase in hospital admissions for chronic bronchitis of $0.33 .3_{6.4} \%$ with a lag of 1 day and $0.122 .85 .7 \%$ with a lag of 4 day for an elevation of TSP with 10 $\mu \mathrm{g} / \mathrm{m}^{3}$ air was registered (Figure 5). Displaying the estimates with confidence intervals as a triple of percentiles 2.550.097.5 is recommended (Louis \& Zeger, 2009). The effects were slightly smaller for the time-series with missing values. For PDLMs the association was significant with an increase of ${ }_{0.01} 1.6_{3.1} \%$ in hospital admissions for chronic bronchitis for an elevation of $10 \mu \mathrm{g} / \mathrm{m}^{3} \mathrm{TSP}$ with a lag of three days.

A threshold analysis revealed there was no level, below which no effect of TSP was present for both lagged TSP effect levels (Figure 6).

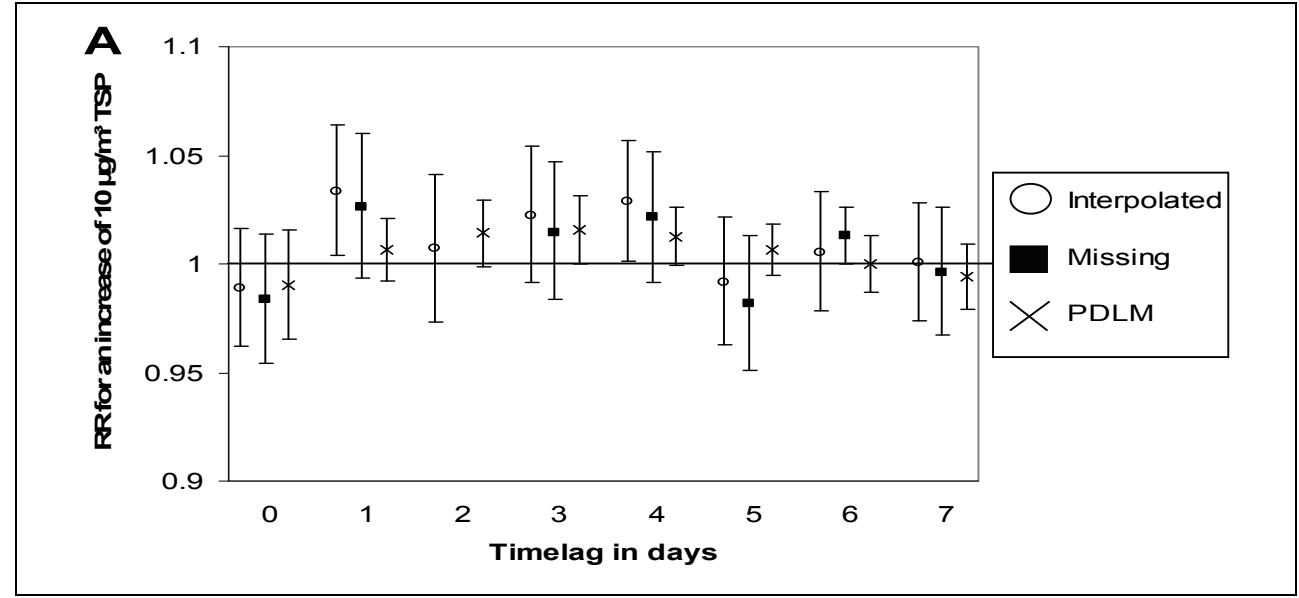

Fig. 5. Relative risk (CI 95\%) for an increase of TSP with $10 \mu \mathrm{g} / \mathrm{m}^{3}$ air in single lag model with original and interpolated data and PDLMs with interpolated data

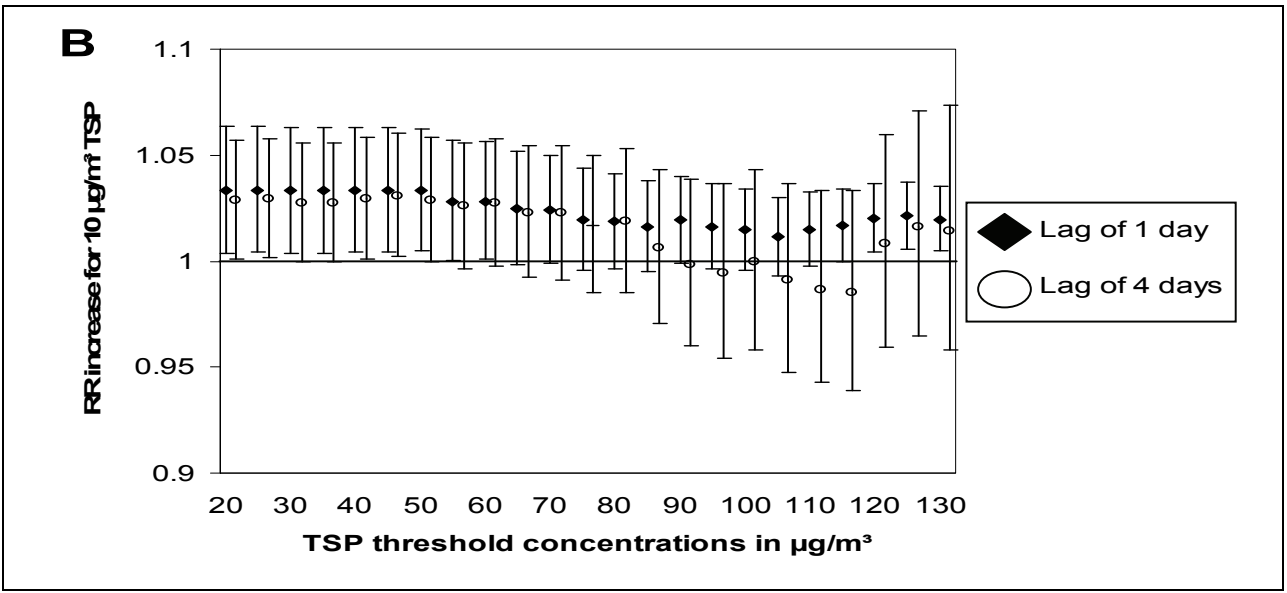

Fig. 6. Relative risk (CI 95\%) for an increase of TSP with $10 \mu \mathrm{g} / \mathrm{m}^{3}$ air using the threshold of 1 day and 4 days 
When we investigated subgroups depending on gender the effect was significant, the number of male hospital admissions increased to $1.64 .09_{7.22} \%$ with a lag of 4 days and the female hospital admissions increased to ${ }_{0.434} 4.44_{8.60} \%$ with a lag of one day TSP exposure (Figure 7).

The modification of the significant effects of TSP by absolute humidity was analysed adding an interaction term between the two variables (Leitte et al., 2009). For low concentration of TSP (less than $60 \mu \mathrm{g} / \mathrm{m}^{3}$ ), increased humidity reduces the risk of hospital admission due to chronic bronchitis (Table 21). Concentrations of TSP of more than $60 \mu \mathrm{g} / \mathrm{m}^{3}$ cancel the antagonistic effect.

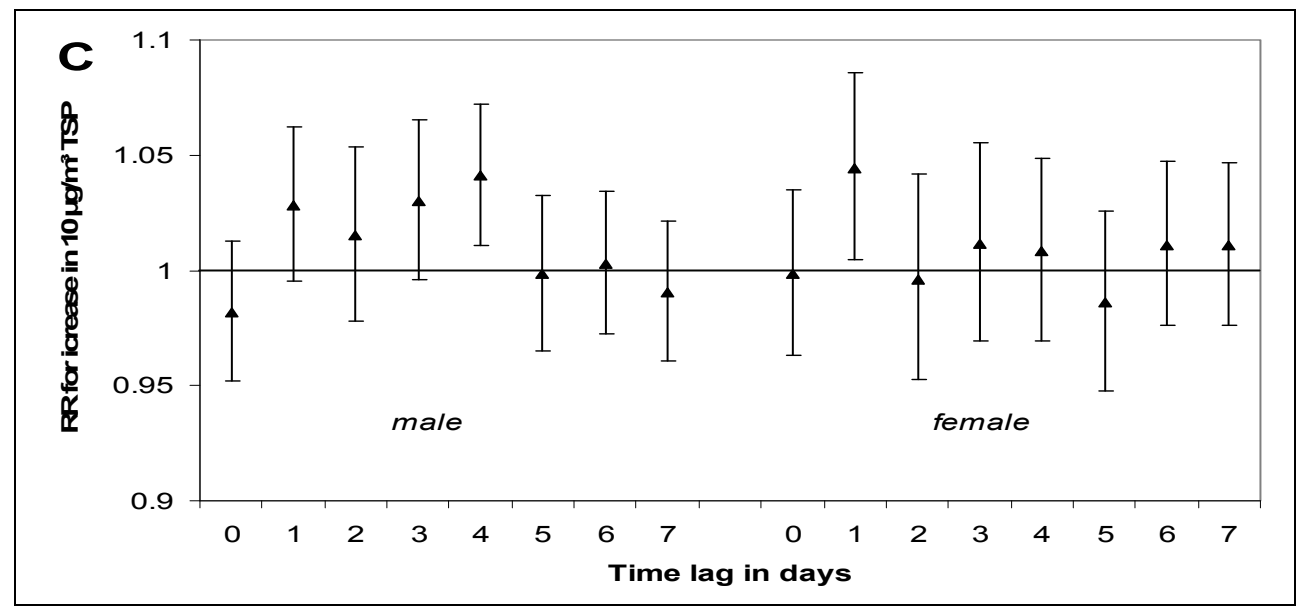

Fig. 7. Relative risk (CI 95\%) for an increase of TSP with $10 \mu \mathrm{g} / \mathrm{m}^{3}$ air for gender subgroups

\begin{tabular}{|c|c|c|}
\hline & $\begin{array}{c}\text { Change of hospital admissions } \\
\text { for chronic bronchitis (\%) }\end{array}$ & $\begin{array}{c}\text { p- } \\
\text { value }\end{array}$ \\
\hline TSP with lag of 1 day & 6.97 & 0.002 \\
\hline $\begin{array}{c}\text { Modification by absolute humidity, moving } \\
\text { the average on the same and last day }\end{array}$ & -0.41 & 0.05 \\
\hline TSP with a lag of 4 days & 6.02 & 0.009 \\
\hline $\begin{array}{c}\text { Modification by absolute humidity with a lag } \\
\text { of 4 days }\end{array}$ & -0.37 & 0.092 \\
\hline
\end{tabular}

Table 21. Modifying effect of TSP (increment of $10 \mu \mathrm{g} / \mathrm{m}^{3}$ ) by absolute humidity (increment of $1 \mathrm{~g} / \mathrm{m}^{3}$ ) on hospital admissions for chronic bronchitis

\section{Effects of $\mathrm{SO}_{2}$ on chronic bronchitis}

We observed a significant increase of $15 \%$ and $9 \%$ hospital admissions due to chronic bronchitis for an increment of $1 \mu \mathrm{g} / \mathrm{m}^{3} \mathrm{SO}_{2}$ with a delay of two or seven days when we considered a time-series with interpolated values. 


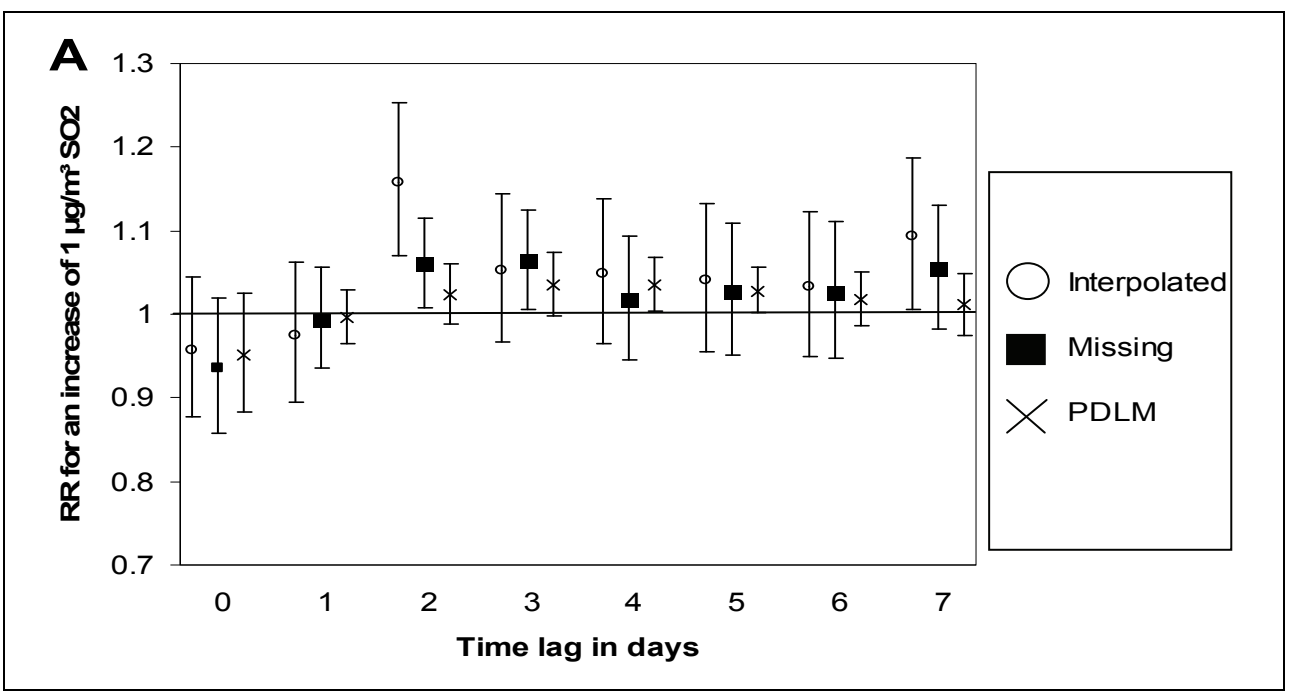

Fig. 8. Relative risk ( $\mathrm{RR}-95 \% \mathrm{CI}$ ) of an increase of $1 \mu \mathrm{g} / \mathrm{m}^{3} \mathrm{SO}_{2}$ (single lag model with interpolated, original data and PDLMs for interpolated data) for hospital admissions for chronic bronchitis and different time lags

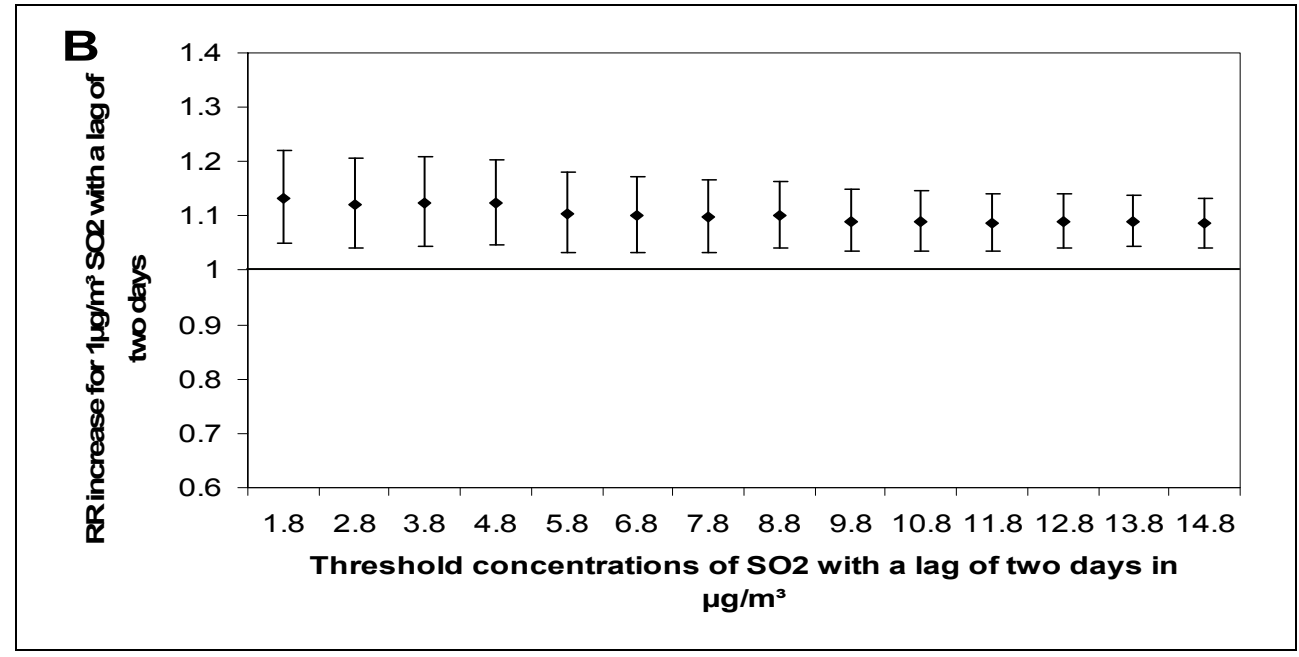

Fig. 9. Relative risk ( $\mathrm{RR}-95 \% \mathrm{CI}$ ) of an increase of $1 \mu \mathrm{g} / \mathrm{m}^{3} \mathrm{SO}_{2}$ for hospital admissions for chronic bronchitis using thresholds for a lag effect of two days

When we considered a time-series with missing values the association was reduced to a ${ }_{1} 6_{12} \%$ and ${ }_{1} 6_{13} \%$ increase of hospital admissions for chronic bronchitis for the same increment with $1 \mu \mathrm{g} / \mathrm{m}^{3} \mathrm{SO}_{2}$ with a lag of two and three days. For PDLMs an increment of 1 $\mu \mathrm{g} / \mathrm{m}^{3} \mathrm{SO}_{2}$ determined an increase of $0.403 .66 .81 \%$ and $0.112 .85 .58 \%$ hospital admissions for chronic bronchitis (Figure 8). 
There was no threshold, under which no adverse effect of $\mathrm{SO}_{2}$ on chronic bronchitis existed (Figure 9).

All significant single pollutant effects were included in a multi pollutant model. In this model the effect of $\mathrm{SO}_{2}$ with a delay of two days remained significant (RR=13\% for a increase of $1 \mu \mathrm{g} / \mathrm{m}^{3} \mathrm{SO}_{2}$ ) and the effect of TSP with a delay of four days became weakly significant $\left(\mathrm{RR}=2.5 \%\right.$ for an increase of $\left.10 \mu \mathrm{g} / \mathrm{m}^{3} \mathrm{TSP}, \mathrm{p}=0.09\right)$. Adverse influences of TSP, $\mathrm{SO}_{2}, \mathrm{NO}_{2}$ on total respiratory admissions, $\mathrm{COPD}$ and asthma, and of $\mathrm{NO}_{2}$ on chronic bronchitis were found, but without statistical significance.

\section{Discussion}

Air pollution with particulate matter and gases is well known in south-eastern Europe, as it is reported in numerous studies performed in this area. High levels of black smoke were found in Serbia (Milutinović et al., 2009), increasing concentrations of $\mathrm{SO}_{2}$ were noticed in Prague (Duben, 1988). In Greece, a study that investigated the gas concentration evolution along the year indicated the powerful influence of the season on the air pollutant levels, being minimal in summer and maximal in winter (Papaioannou et al., 2010). A "Convention on Long-Range Trans-boundary Air Pollution (CLRTAP)" was opened for signature in 1979 and came into force in 1983. This Convention has now 51 parties and priority activities include review and possible revision of its most recent protocols with special focus on Eastern Europe and South Eastern Europe.

In our study, we found an increased level of air pollution with particles $\left(134 \mathrm{\mu g} / \mathrm{m}^{3}\right.$ air in the first study period and $111.42 \mu \mathrm{g} / \mathrm{m}^{3}$ air or $123.45 \mu \mathrm{g} / \mathrm{m}^{3}$ air in the second study period) and gases $\left(4.68 \mu \mathrm{g} \mathrm{SO} / \mathrm{m}^{3}\right.$ air and $11.8 \mu \mathrm{g} \mathrm{NO} / \mathrm{NO}^{3}$ air - in the second study period - 1 year), which surpasses the maximal admitted concentrations of TSP for the United States (75 $\mu \mathrm{g} / \mathrm{m}^{3}$ air) and the maximal admitted concentration of PM10 specified by the European Commission $\left(40 \mu \mathrm{g} / \mathrm{m}^{3}\right.$ air corresponding to $57-133 \mu \mathrm{g} / \mathrm{m}^{3}$ air TSP) and are lower than the maximal admitted concentration of gases $\left(\mathrm{SO}_{2}-20 \mu \mathrm{g} / \mathrm{m}^{3}\right.$ air and $\mathrm{NO}_{2}-40 \mu \mathrm{g} / \mathrm{m}^{3}$ air $)$ (2008/50/EC).

Climate change and climate factors influence both air pollution and human health (Mc Michael et al., 2008) and is also a largely investigated topic. Climate change was not found to have high impact on the distribution of the deposition, nor did regional air pollution (in the form of sulphate aerosols) (Alcamo et al., 2002). In our study, we also did not find an association between climatic factors and air pollutants. Variations in meteorological parameters were evident between the two periods under study: average temperature increased from $11.82^{\circ} \mathrm{C}$ to $12.78^{\circ} \mathrm{C}$; average relative air humidity decreased from $74.5 \%$ to $67.96 \%$ and wind velocity from $1.97 \mathrm{~m} / \mathrm{s}$ to $5.64 \mathrm{~m} / \mathrm{s}$. These results are similar with other results from literature (Kovats et al., 1999; Wjingaarden \& Vincent, 1995). In literature an association climate factors - respiratory health was found, especially between air temperature, humidity and asthma (Weiland et al., 2004). In our study, the first period, we identified a protective effect of air relative humidity on asthma (Spearman correlation), and in the second period of study first time-series analysis was revealed a protective effect of absolute air humidity on chronic bronchitis and asthma. Analysing the evolution of results between the two approaches of the first time-series analysis, we noticed seasonality as a powerful confounding factor, this being considered only in the second approach. The greatest confusion created by seasonality was present especially in the case of COPD (chronic obstructive pulmonary diseases) when humidity transformed itself from a 
protective factor on COPD into an adverse one, between the two approaches. The seasonal influence on COPD admission in hospital was modelled by a spline function of seasonality with local minima in summer and local maxima in winter.

Respiratory health appeared as being frequently impacted by air pollution. Many epidemiological studies described the long term effects of air pollutants on the population with chronic respiratory diseases, such as the impact on symptoms investigated in Switzerland (Zemp et al., 1999), symptoms which occurred in children exposed to air pollution in the Netherlands (Brauer et al., 2002; Abbey et al., 1995), or the impact of air pollution on other chronic diseases as carcinoma (Chen \& Goldberg, 2009). Respiratory health evolution was difficult to analyse between the two study periods, because of different approaches. Only a qualitative comparison between the two study periods was possible. A similar approach was considered necessary in China, where short-term effects were studied (numerous time-series analyses). Long-term effects of air pollutants on health are less studied so far (Kan et al., 2009).

Case-control studies proved to be useful for the investigation of long-term effects of air pollution on health, investigating especially the respiratory symptoms (Burr et al., 2004). Some authors analysed the study performed in South-Eastern Europe, exposing the bad management of resources in this area and the great levels of air pollution (especially sulphur dioxide) (Jedrychowski, 1995). The case-control study performed in the first period of study offered results about long-term effects of air pollution with TSP on new cases of hospitalisation for chronic respiratory diseases. A similar study on hospital attendance due to respiratory diseases as a result of air pollution effects was made in Turin, Italy (Migliareti et al., 2007). A significant result of the first study period was the impact of outdoor air pollution on COPD at different ages, in the active population and the elderly. Similar results were obtained analysing some epidemiological studies performed in developing and industrialized countries (Viegi et al., 2006).

Short-term effects of air pollution on respiratory health were frequently approached by researchers in the area, revealing the weak effect of particulate matter and the stronger effect of sulphur dioxide on respiratory health in Paris (Dab et al., 1996), the effect of fine particulate matter on cardiovascular disease and carcinoma (Laden et al., 2006), or the association of elderly population exposed to higher risk of mortality (Gouvea \& Fletcher, 2000). The two time-series analyses performed in the second study period made possible an evaluation of the short-term risk of the TSP (both analysis) and SO2 and NO2 (the second analysis) on respiratory health.

The impact of air pollution with particles on chronic bronchitis was showed in literature (Herbarth et al., 2001). Although, initially, air pollution was investigated for high levels of exposure, there is also a tendency to investigate air pollution effects on low levels (Pope et al., 1995). This approach is also supported by the results of our study, we did not find a threshold under which no effects occur for TSP and sulphur dioxide. Although the study designs were different, the impact of TSP on chronic bronchitis at a specific age (15-64 years in the first study period, 18-44 years in the second study period) was evident. In our study, active population seems to be more exposed to outdoor air pollution. Similar results were found in literature, a significant number of cases of chronic bronchitis being found in adults by a study in Barcelona (Kunzli \& Perez, 2007).

In the second time-series analysis of the second study period, significant results were found only for chronic bronchitis due to air pollution with TSP and gases $\left(\mathrm{SO}_{2}\right)$ using an extension 
of the time delayed effect from 1 day (in the first time-series analysis) to 7 days, PDLMs for interpolated series and an interaction term in order to observe the modifying effect of absolute humidity. Seasonality as a confounding factor was always considered.

For a single lag model, the hospital admissions for chronic bronchitis increased with $3.3 \%$ for a lag of 1 day and with $2.8 \%$ for a lag of 4 days due to an increase of TSP by $10 \mu \mathrm{g} / \mathrm{m}^{3}$ air (interpolated series). The effect was lower for the series with missing values and more realistic for the series with PDLMs. When we included the TSP effect on chronic bronchitis in the multi pollutant model, the relative risk remained weakly significant $(R R=2.5 \%$ for an increase of $10 \mu \mathrm{g} / \mathrm{m}^{3} \mathrm{TSP}, \mathrm{p}=0.09$ ), only for a lag of 4 days. The modifying effect of absolute humidity on the effect of TSP on chronic bronchitis was present and statistically significant for a time lag of 2 days and TSP concentrations lower than $60 \mu \mathrm{g} / \mathrm{m}^{3}$ air, with a decrease of $0.41 \%$ admitted cases $(p=0.05)$ to an increase in $1 \mathrm{~g} / \mathrm{m}^{3}$ air absolute humidity. The differences between health effects according to sex were described in literature (Kenedy et al., 2007). In our study, the effect for hospital admissions was more delayed and slightly lower for male admissions, but these differences between sexes are not statistically significant.

The single lag model also registered an increase of chronic bronchitis with $15 \%$ for a lag of 2 days and $9 \%$ for a lag of 7 days, for an enhancing with $1 \mu \mathrm{g} / \mathrm{m}^{3}$ air $\mathbf{S O}_{2}$, considering interpolated series. When we considered the series with PDLMs the increase of chronic bronchitis admissions was lower than $3.6 \%$ and $2.8 \%$ for a lag of 2 and 3 days, respectively, of $\mathrm{SO}_{2}$ increment with $1 \mu \mathrm{g} / \mathrm{m}^{3}$ air. The series with PDLMs indicated more realistic results, similar with the data found in literature (Wilson et al., 2005). When we included $\mathrm{SO}_{2}$ effect on chronic bronchitis on multi pollutant model, the relative risk remained statistically significant ( $R R=13 \%$ for a increase of $\left.1 \mu \mathrm{g} / \mathrm{m}^{3} \mathrm{SO}_{2}\right)$, only for a lag of 2 days. In this multi pollutant model there was no correlation between $\mathrm{SO}_{2}$ and TSP and multicolinearity should be negligible. In our study, we did not find a threshold for TSP, neither for $\mathrm{SO}_{2}$. This result indicates the necessity of considering low levels of air pollution as a factor with possible respiratory health impact, too. Air pollution in Drobeta Turnu-Severin, Romania, represents a risk factor for respiratory health of the exposed population, especially because of high levels of $\mathrm{SO}_{2}$ and TSP in outdoor air. Increased air humidity of this area is a protective factor for people with chronic bronchitis and asthma.

\section{Conclusion}

Outdoor air pollution is a reality in Drobeta Turnu-Severin Romania, beginning during the communist period and continuing after the revolution. High levels of TSP and sulphates registered in the eighth decade of the past century diminished in time, but not in a sufficient amount to avoid its impact on health. The monitoring system of air pollution has a tendency to diminish its potential. The Danube and the accumulation lake "Iron Gates" change the climate factors and the ecosystem in the area. Humidity is higher than in other areas of the region and it affects the relationship air pollution - respiratory health, acting as a protective factor on specific chronic respiratory diseases as chronic bronchitis and asthma. The different study designs (case-study for the first study -8 years and time-series analysis for the second successive study -4 years) indicated similar results regarding the TSP effect on chronic bronchitis in active population. A short period of time extended as procedures timeseries analysis (1 year) included in the second study indicated similar results for TSP and $\mathrm{SO}_{2}$ on chronic bronchitis, also revealing the delayed effects of 4 days or 2 days respectively 
for both pollutants. Air humidity appeared as modifying the effect of TSP on chronic bronchitis for a delayed effect of 2 days, revealing itself as being protective. A limitation of the study results consists regards the action of TSP and humidity on COPD. In the first study period, the long-term exposure of the population to TSP acted as a trigger factor for COPD, in active and elderly population. In the second study period, TSP and humidity seemed to have an antagonistic effect on COPD. Moreover, seasonality determined a specific evolution of this disease during the year. A powerful impact of seasonality referred to the action of TSP on asthma, the differences of results between the two approaches of the second study period, in the first time-series analysis being huge. New studies are necessary in order to clarify these aspects.

\section{Acknowledgments}

This study was performed with the financial support of the BMBF (Bundesministerium fur Bildung und Forschung), MECT (Ministerul Educatiei, Cercetarii si Tineretului), $6^{\text {th }}$ Framework Program of the European Commission, Project NoMiracle (Contract No. 003956).

\section{References}

2008/50/EC. (2008). Directive 2008/50/EC of the European Parliament and of the Council of 21 May.

Abbey, D.; Nishino, N.; McDonnell, W.; Burchette, R.; Knutsen, S.; Beeson, L. \& Yang, J. (1999). Long-term inhalable particles and other air pollutants related to mortality in nonsmokers, Am. J. Respir. Crit. Care Med., Volume 159, No. 2, pp. 373-382.

Alcamo, J,; Meyerhofer, P.; Guardans, R.; Van Harmelen, T.; van Minnen, J.; Onigkeit, J.; Posch, M. \& de Vries, B. (2002). An integrated assessment of regional air pollution and climate change in Europe: findings of the AIR-CLIM Project, Environental Scienc $\mathcal{E}$ Policy, Volume 5, No. 4, pp. 257-272, doi: 10.1016/SI 462-9011(02)00037-0.

Atkinson, R. \& al. (2001). Acute effects of particulate air pollution on respiratory admissions - results from APHEA 2 project, Am J Respir Cell Mol Biol, No. 164, pp. 1860-1866.

Brauer, M. \& al. (2002). Air pollution from traffic and the development of respiratory infections and asthmatic and allergic symptoms in children, American Journal of Respiratory and Critical Care Medicine, Volume 166, pp. 1092-1098.

Burr, M.; Karani, G.; Davies, B.; Holmes, B. \& Williams, K. (2004). Effects on respiratory health of a reduction in air pollution from vehicle exhaust emissions, Occup Environ Med., Volume 61, No. 3, pp. 212-218.

Chen, H. \& Goldberg, S. (2009). The effects of outdoor air pollution on chronic illnesses, McGill J Med, Volume 12, No. 1, pp. 58-64.

Chen, M. \& Mao, I. (1998). Spatial variations of airborne particles in metropolitan Taipei, Sci Total Environ, No. 209, pp. 226-231.

Choukiker, S. (2005). Major air pollution episodes: Environmental distortions that kill. An account of major air pollution episodes and their repercurssions arguing for a responsible environmental awareness, Environment: Disaster Management, http:/ / www.visionriviewpoint.com/print.ap?articleid=26.

Dab, W.; Medina, S.; Quénel, P.; Le Moullec, Y.; Le Tertre, A. ; Thelot, B. ; Monteil, C. ; Lameloise, P. ; Pirard, P. ; Momas, I. ; Ferry, R. \& Festy, B. (1996). Short term 
respiratory health effects of ambient air pollution : results of the APHEA project in Paris, J. Epidemiol Community Health., Volume 50, Suppl. 1, s42-s46.

Dennis, R.; Maldonado, D.; Baena, E. \& Martinez, G. (1996). Woodsmoke exposure and risk for obstructive airway disease among women, CHEST, Volume 109, No. 1, pp. 115119.

Duben (transl) Giustino, K. (1988). Air quality in Prague, Lidove Noveni, pp. 7.

Fang, G.; Chang, C.; Wu, Y.; Fu, P.; Chang, K. \& Yang, D. (1999). The characteristic study of TSP, PM10 and PM2.5 in the rural site of central Taiwan, Sci Total Environ, No. 232, pp. 177-184.

Gouvea, N. \& Fletcher, T. (2000). Time-series analysis of air pollution and mortality effects by cause, age and socioeconomic status, J Epidemiol Community Health, Volume 54, pp. 750-755.

Hastie, T. \& Tibshirani, R. (1987). Generalized Additive Models: some applications (with discussion), JASA, No. 82, pp. 371-386.

Herbarth, O. \& al. (2001). Effect of sulfur dioxide and particulate pollutants on bronchitis in children - a risk analysis, Environ Toxicol, Volume 16, No. 3, pp. 269-276.

Jedrychowski, W. (1995). Review of recent studies from central and Eastern Europe associating respiratory health effects with high levels of exposure to "traditional" air pollutants, Environ Healh Perspect., Volume 103, Suppl. 2, pp. 15-21.

Kan, H.; Chen, B. \& Hong, C. (2009). Health Impact of Outdoor air pollution in China: current knowledge and future research needs, Environ Health Perspect, Volume 117, No. 5, pp. A187.

Kelly, F.; Dunster, C. \& Mudway, I. (2003). Air pollution in the elderly: oxidant/antioxidant issues worth consideration, Eur. Respir. J. Suppl., No. 40, 70s-75s.

Kennedy, S.; Chambers, R.; Du, W. \& Dimich-Ward, H. (2007). Environmental and occupational exposures: do they affect chronic obstructive pulmonary disease differently in women and men?, Proc Am Thorac Soc, Volume 4, No. 8, pp. 692-694.

Kowats, R.; Haines, A.; Stanwell-Smith, R.; Martens, P.; Menne, B. \& Bertolini, R. (1999). Climate change and human health in Europe, BMJ, No. 318, pp. 1682-1685.

Kunzli, N. \& Perez, L. (2007). The public health benefits of reducing air pollution in Barcelona metropolitan area, www.creal.cat/media/upload/arxius/.../informecontaminacio-eng.pdf.

Kurmi, O.; Semple, S.; Simkhada, P.; Smith, W. \& Ayres, J. (2009). COPD and chronic bronchitis risk of indoor air pollution from solid fuel: a systematic review and meta-analysis, Thorax, Volume 65, pp. 221-228, doi: 10.1136/thx.2009.124644.

Laden, F.; Schwartz, J.; Speizer, F. \& Dockery, D. (2006). Reduction in fine particulate air pollution and mortality, American Journal of Respiratory and Critical Care Medicine, Vol. 173.

Leitte, A.; Petrescu, C.; Franck, U.; Richter, M.; Suciu, O.; Ionovici, R.; Herbarth, O. \& Schlink, U. (2009). Respiratory health, effects of ambient air pollution and its modification by air humidity in Drobeta-Turnu Severin, Romania. Science of the Total Environment, No. 407, 4004 - 4011.

Leonardi, G.; Houthuijs, D.; Nikiforov, B.; Volf, J.; Rudnai, P. \& Zejda, J. (2002). Respiratory symptoms, bronchitis and asthma in children of Central and Eastern Europe. Eur. Respir. J., Volume 20, No. 4, pp. 890-898. 
Lindgren, A.; Stroh, E.; Montnemery, P.; Nihlen, U.; Jakobson, K. \& Axmon, A. (2009). Traffic-related air pollution associated with prevalence of asthma and COPD/chronic bronchitis. A cross-sectional study in Southern Sweden, Int J Health Geogr., Volume 8, No. 2, doi: 10.1186/1476-072X-8-2.

Linn, W.; Szlachcic, Y.; Gong, H. \& Berhane, K. (2000). Air pollution and daily hospital admissions in metropolitan Los Angeles, Environ.Health Perspect., Volume 108, No. 5, pp. 427-434.

Louis, T.A.; Zeger, S.L. (2009). Effective communication of standard errors and confidence intervals, Biostatistics, Volume 10, No. 1, pp. 1-2.

McMichael, A. \& al. (2008). International study of temperature, heat and urban mortality: the ISOTHURM project, Int J Epidemol, Volume 37, No. 5, pp. 1121-1131.

Migliaretti, G.; Damalso, P. \& Gregori, D. (2007). Air pollution effects on the respiratory health of the resident adult population in Turin, Italy, International Journal of Environmental Health Research, Volume 17, No. 5, pp. 369-379.

Milutinović, S.; Nikić, D.; Stosić, L.; Stanković, A. \& Bodanović, D. (2009). Short-term association between air pollution and emergency-room admissions for chronic obstructive pulmonary disease in Nis, Serbia, Cent Eur J Public health, Volume 17, No. 1, pp. 8-13.

Monn, C. (2001). Exposure assessment of air pollutants: a review on spatial heterogeneity and indoor/outdoor/personal exposure to suspended particulate matter, nitrogen dioxide and ozone, Atmospheric Environment, Volume 35, No. 1, pp. 1-32.

National Institute of Statistics of Romania, Romanian Statistical Yearbook. (2006). http://www. insse.ro/cms/rw/pages/index.en.do [acesed 30 september 2008].

Papaioanou, A.; Viras, L.; Nastos, P. \& Paliatsos, A. (2010). Temoral evolution of sulfur dioxide and nitrogen oxides in the city of Volos, Greece, Environ Monit Assess., Volume 161, No. 1, pp. 485-494.

Pope, A.; Bates, D.\& Raizenne, M. (1995). Health effects of particulate air pollution: time for reassessment?, Environmental Health, Volume 103, pp. 472-480.

Ritz, T.; Meuret, A.; Wilhelm, F. \& Roth, W. (2009). Changes in pCO2 symptoms, and lung function of asthma patients during capnometry - assisted breathing training, Applied Psychophysiology and Biofeedback, No. 34, pp. 1-6.

Simoni, M.; Jaakkola, M.; Carrozzi, L.; Baldacci, S.; Di Pede, F.; Yiegi, G. (2003). Indoor air pollution and respiratory health in the elderly, ERJ, Volume 21, No. 40 suppl. 15s20s.

Stull, R. (2000). Meteorology for scientists and engineers, In: Pacific Grove California, Brooks Cole.

The HEAPS project Health Effect of Air pollution on Susceptible Subpopulation, study design. (2003). Air pollution and recruitment of Myocardial Infarction patients, Epidemiology, Volume 14, No. 5, pp. 591-592.

Van Wjingaarden, W. \& Vincent, L. (2005). Trends in relative humidity n Canada from 19532003, J. Geophys. Res., 110, D22102, doi: 10.1029/2005JD05925, http://www.yorku. ca/wlaser/publications/Papers\%20(PDF\%20Format)/2006/2006_3.pdf.

Viegi, G.; Maio, S.; Pistelli, F.; Baldacci, S. \& Carrozzi, L. (2006). Epidemology of chronic obstructive pulmonary disease: health effects of air pollution, Respirology, pp. 523532, doi: 10.1111/j1400-1843.2006.00886.x. 
Weiland, S.; Husing, A.; Strachan, D.; Rzehac, P. \& Pearce, N. (2004). Climate and the prevalence of symptoms of asthma, allergic rhinitis, and atopic eczema in children, Occup.Envion. Med., No. 61, pp. 609-615.

Wilson, A. \& al. (2005). Air pollution, weather, and respiratory emergency room visits in two northern New England cities: an ecological time-series study, Environ Res, Volume 97, pp. 312-321.

Wong, T.; Lau, T.; Yu, S.; Neller, A.; Wong, S.; Tam, W. \& Pang, S. (1999). Air pollution an hospital admissions for respiratory and cardiovascular diseases in Hong Kong, Occup. Environ. Med., Volume 56, No. 10, pp. 679-683.

Wood, S. (2006). Generalized Additive Models: an introduction with R. In: Chapman and Hill/CRC, New York.

Zanobetti, A. \& Schwatz, J. (2003). Air pollution and emergency admissions in Boston, MA, J Epidemiol Community Health, No. 60, pp. 890-895.

Zemp, E. \& al. (1999). Long-term ambient air pollution and respiratory symptoms in adults (SAPALDIA study), Am J Respir Crit Care Med., Volume 159, No. 4, pp. 1257-1266.

Zielinski, J.; Macnee, W.; Wedzicha, J.; Ambrosino, N.; Braghiroli, A.; Dolensky, J.; Howard, P.; Gorzelak, K.; Lahdensuo, A.; Strom, K.; Tobiasz, M. \& Weitzenblum, E. (1997). Causes of death in patients with COPD and chronic respiratory failure, Monaldi Arch Chest Dis., Volume 52, No. 1, pp. 43-47. 


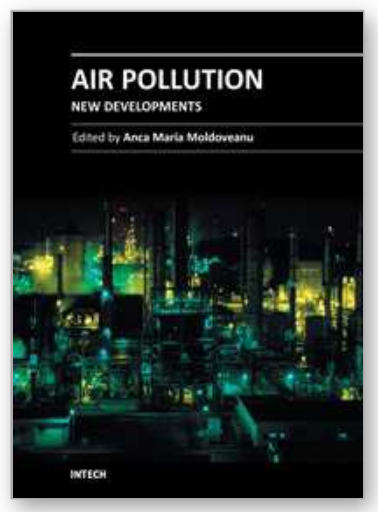

\author{
Air Pollution - New Developments \\ Edited by Prof. Anca Moldoveanu
}

ISBN 978-953-307-527-3

Hard cover, 324 pages

Publisher InTech

Published online 06, September, 2011

Published in print edition September, 2011

Today, an important issue is environmental pollution, especially air pollution. Due to pollutants present in air, human health as well as animal health and vegetation may suffer. The book can be divided in two parts. The first half presents how the environmental modifications induced by air pollution can have an impact on human health by inducing modifications in different organs and systems and leading to human pathology. This part also presents how environmental modifications induced by air pollution can influence human health during pregnancy. The second half of the book presents the influence of environmental pollution on animal health and vegetation and how this impact can be assessed (the use of the micronucleus tests on TRADESCANTIA to evaluate the genotoxic effects of air pollution, the use of transplanted lichen PSEUDEVERNIA FURFURACEA for biomonitoring the presence of heavy metals, the monitoring of epiphytic lichen biodiversity to detect environmental quality and air pollution, etc). The book is recommended to professionals interested in health and environmental issues.

\title{
How to reference
}

In order to correctly reference this scholarly work, feel free to copy and paste the following:

Cristina Petrescu, Oana Suciu, Romanita Ionovici, Olf Herbarth, Ulrich Franck and Uwe Schlink (2011). Respiratory Health Effects of Air Pollution and Climate Parameters in the Population of Drobeta Turnu-Severin, Romania, Air Pollution - New Developments, Prof. Anca Moldoveanu (Ed.), ISBN: 978-953-307-527-3, InTech, Available from: http://www.intechopen.com/books/air-pollution-new-developments/respiratory-health-effects-ofair-pollution-and-climate-parameters-in-the-population-of-drobeta-turn

\section{INTECH}

open science | open minds

\section{InTech Europe}

University Campus STeP Ri

Slavka Krautzeka 83/A

51000 Rijeka, Croatia

Phone: +385 (51) 770447

Fax: +385 (51) 686166

www.intechopen.com

\section{InTech China}

Unit 405, Office Block, Hotel Equatorial Shanghai

No.65, Yan An Road (West), Shanghai, 200040, China

中国上海市延安西路65号上海国际贵都大饭店办公楼 405 单元

Phone: +86-21-62489820

Fax: +86-21-62489821 
(C) 2011 The Author(s). Licensee IntechOpen. This chapter is distributed under the terms of the Creative Commons Attribution-NonCommercialShareAlike-3.0 License, which permits use, distribution and reproduction for non-commercial purposes, provided the original is properly cited and derivative works building on this content are distributed under the same license. 